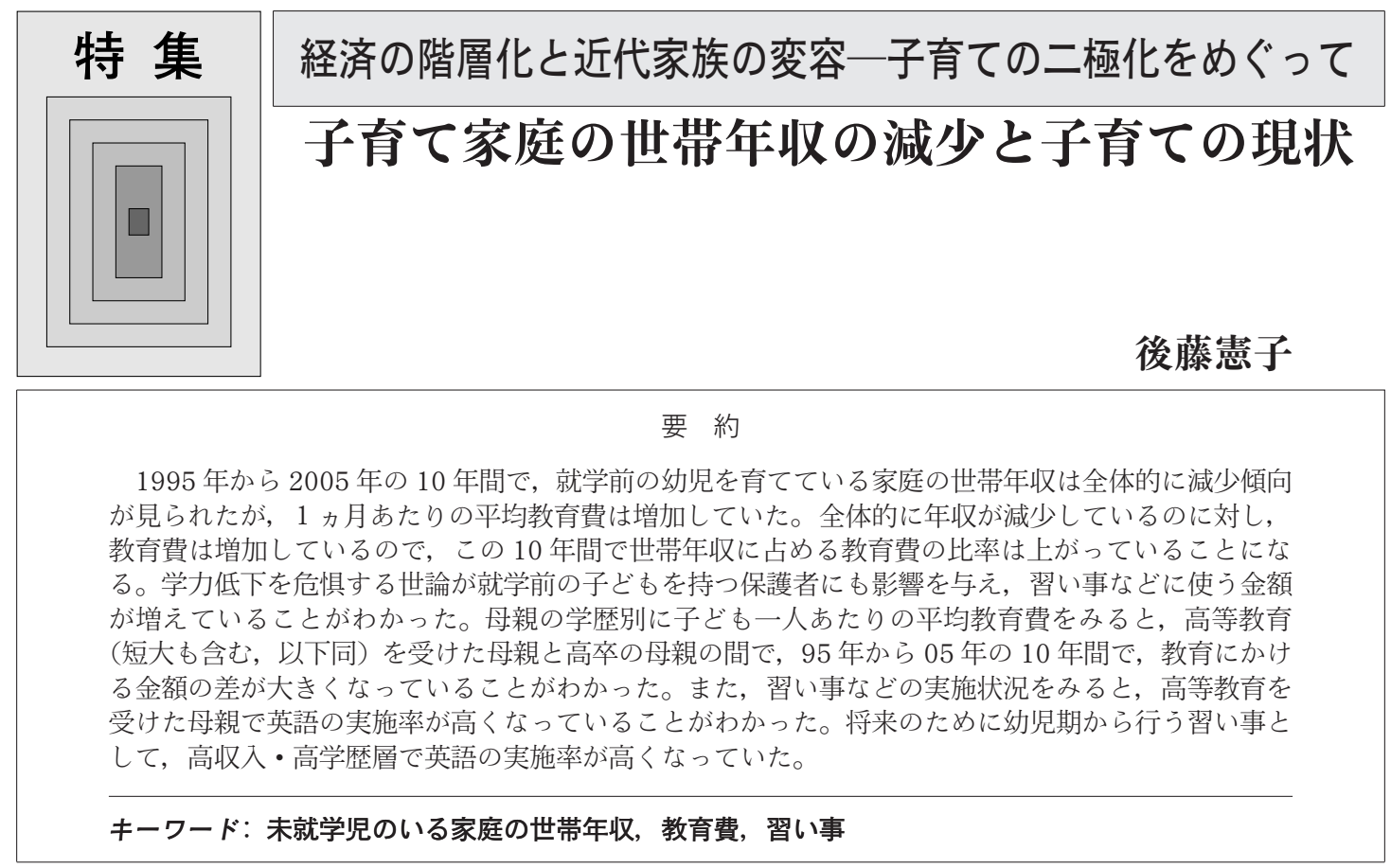

2009 , 家族社会学研究, 21(1): 21-29

\title{
The Declining Annual Income of Families with Children and Its Effect on Child-rearing
}

Noriko Goto

Abstract
During the decade from 1995 to 2005, the annual household income of families with preschool
children declined overall, while average monthly educational expenses rose. As income fell and
educational expenses rose, educational expenses accounted for an increasingly greater percent-
age of total household income. Public anxiety over declining scholastic aptitude extended to
parents of preschoolers, who increased expenditures for lessons and instructional services for
their children. In a comparison of mothers with higher education (hereafter, junior college
education or above) and high-school-graduate mothers, the difference in average educational
expenses per child by educational background of the mother grew during the same decade. In
terms of lesson type, among mothers with higher education, the percentage of children taking
English lessons rose. In the high-income and higher-education bracket, where English lessons
begin from early childhood as a way to prepare for the future, the percentage of preschoolers
taking English lessons increased.

Key words: household income of families with preschool children, educational expenses, lessons

2009, Japanese Journal of Family Sociology, 21(1): 21-29

ごとうのりこ：ベネッセ次世代育成研究所

Benesse Institute for the Child Sciences and Parenting, Jinbo-cho Mitsui Bldg., 1-105 Kanda Jinbo-cho, Chiyoda-ku, Tokyo 101-8685, Japan 
失われた 10 年と呼ばれた平成不況が幕を閉 じ, 経済が安定してきたなかで格差の問題が浮か び上がってきた。就職する世代の人たちにとって は，正規・非正規雇用の問題があり，都市部の小 学生の子どもを持つ家庭では一部の私立中学を受 験する層と, 公立中学に進む層に分かれてきてい る。受験対象となる私立はほとんどが中高一貫校 のため, 6 年間授業料を払い続ける経済力が必要 となる。また, 受験隼備の塾の費用も必要となる。 それらの金額は年間百万円近くになることもあ り, 親の所得により, 受験できるかどうかが分か れる。

では, 中学受験のような膨大な家計支出を必要 としない, 就学前の子どものいる家庭の現状はど うなっているのだろうか。「格差」という形で大き な問題が起こっているようには見えないが，習い 事の選び方や子育て環境に違いが見られる可能性 がある。また, 経済状況によって, 子育て意識に 屯違いが見られると思われる。ベネッセコーポ レーションの調査研究部門が実施してきた, 乳幼 児をむつ家庭を対象とした調査を再分析し，そこ から見えてきたことを取り上げてみる。なお，こ れらの調査は基本調査という枠組みで行われ, 家 庭での子育て環境を幅広くとらえることを目的と している。「格差」を論じることを目的とした調査 ではないため, ここで紹介するデー夕は生活全般 に関する調査結果の一部を用いての断片的分析と
なっていることをあらかじめお断りしておきた い。

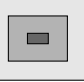

\section{1995 年から 2005 年の子育て 家庭の世帯年収について}

就学前の子どあがいる家庭の世帯年収はどれく らいなのだろうか。ベネッセで 2005 年に実施し た『乳幼児の父親についての調査』(1) と2006 年 に行った『妊娠出産子育て基本調査』(2) では, 400 〜600 万円未満が全体の約 3 割を占めていた。父 親の年齢も 35 歳前後が最も多く, この年代の収 入を反映していると言えるだろう。

また，過去からの経年比較ができる『幼児の生 活アンケート』(3) の世帯年収の推移をまとめたも のが図 1 である。調査は 1995 年, 2000 年, 2005 年に実施された (以下, 95 年, 00 年, 05 年 と表記)。この時期はバブル崩壊の影響を受け, 不 況が深刻化し始めた 95 年から消費が最む冷え込 んだ 00 年頃を経て, 小泉内閣が成立し景気が回 復していく 05 年までの 10 年間と重なる。この 間, 子育て家庭の世帯年収はどのように推移して いったのだろうか。

図 1 は年収を 200 万円刻みにしたときの分布 を表している。9 5 年, 00 年, 05 年の 5 年ごとに 見たときに最も増加しているのは，年収 $200 〜$ 400 万円未満の層だった（95 年 5.5\%，00 年 $7.9 \%, 05$ 年 $13.2 \%) 。$ 一方で年収 600 万円以上

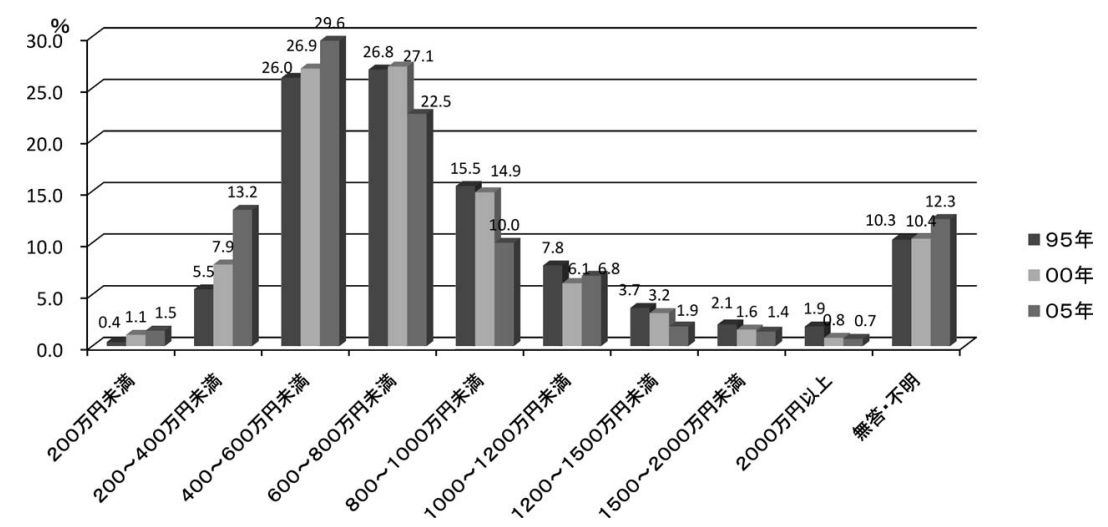

図 1 幼児の生活アンケート 世帯年収の推移 
の層は, ほぼどの層でも減少傾向が見られる。減 少幅が大きいのは年収 800 1000 万円未満で, 95 年の $15.5 \%$ に対し 05 年は $10.0 \%$ と， 5.5\%減 少している。しばしば「二極化している」と言わ れるが，このデータを見る限り低〜中所得層の割 合が増加し, 年収 600 万円以上の経済的にゆとり のある層の割合が減少していることが見て取れ る。全体的に所得が低いほうへとシフトしている のである。

\section{口 II. 教育費と習い事の変化}

\section{1 カ月あたりの平均教育費の変化}

『幼児の生活アンケート』の中では, 教育費(こ こでいう教育費とは 1 力月あたりの塾・習い事 などにかかる費用であり, 幼稚園・保育所にかか る費用は除いたあのである）に関する質問を継続 して行ってきた。調査対象となった子どあの 1 力 月あたりの平均教育費は, 95 年 8,556 円, 00 年 7,323 円，05 年 8,771 円と推移していた（図 2)。 00 年は不況の影響を受けたためか教育費も大幅 に削られ，95 年と比較すると 1,233 円も低く なっている。それに対し，景気が回復した 05 年 は 00 年よりも 1,448 円増加し, 平均額は 10 年 前の 95 年を上回った。世帯年収は 95 年から 05 年の 10 年間で全体的に減少傾向が見られたが, 逆に教育費は増えていることがわかる。世帯年収 に占める教育費の割合は高くなっているはずで, この 10 年間で, 乳幼児を育てている保護者たち あより熱心に教育投資するようになっていること がわかる。

しかし，すべての家庭で教育費が増えていると は限らないので, 年収層や母親の学歴によってど のような推移があるのかを見てみた。

世帯年収を 400 万円未満, 400 600 万円未 満，600 800 万円未満，800～1000 万円未満, 1000 万円以上の 5 層に分け, 平均教育費の 10 年間の推移をみた（図 3-1)）。年収の高い層ほよ゙ 平均教育費が高く, 400 万円未満を除く他の年収 層では, 00 年にいったん減少するものの, 05 年

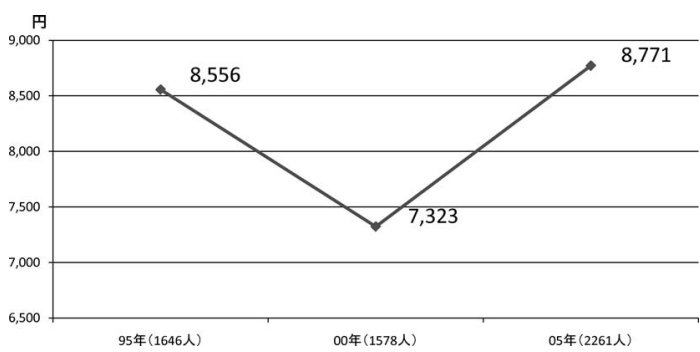

図 2 幼児の生活アンケート 1 カ月あたりの平均 教育費の推移

注 1）教育費 $=1$ 力月あたりの塾・通信教 育・習い事・絵本・玩具にかかる費 用. 幼稚園・保育園にかかる費用は 除く.

注 2) 1 人あたりの 1 力月の平均教育費は $\lceil 1,000$ 円未満」を 500 円，「1,000〜 5,000 円」を 3,000 円，「30,000 円以 上」を 32,000 円のように置き換えて 算出. 無答不明は分析から除外 (以 下同様).

には 95 年を上回る回復を見せている。とくに年 収 800〜 1000 万円未満の層は 05 年と 95 年を比 較すると 1,595 円増, $600 \sim 800$ 万円未満は 1,225 円増加している。年収 400 万円未満はもと あと教育費が少ないこともあってか, 95 年の 5,137 円に対し， 00 年は 5,261 円と微増し， 05 年には 6,086 円に増加している。年収層別に見る と, 年収が高い層ほど教育費が高く, 95 年から 05 年の 10 年間でその傾向に変わりないことが, また，どの年収層でも教育費が増加したことがわ かる。

では，母親の学歴との関係はどうなっているだ ろうか。母親が四年制大学卒 (以下, 四大卒と表 記）の場合，95 年に 10,577 円だった平均教育費 は 00 年に 8,142 円に減少し, 05 年に 9,980 円に 回復するものの, 95 年の平均額には戻っていな い。短大卒の場合, 95 年に 8,912 円だったのが, 00 年に 7,684 円と一度減少するが，05 年には 9,625 円に回復し, 95 年の平均額を上回り, 四大 卒との差が縮まっている。高卒も同じような推移 を見せているが, 出費額は四大卒, 短大卒と比較 すると低い（図 3-(2) 中卒の場合, サンプル数が 


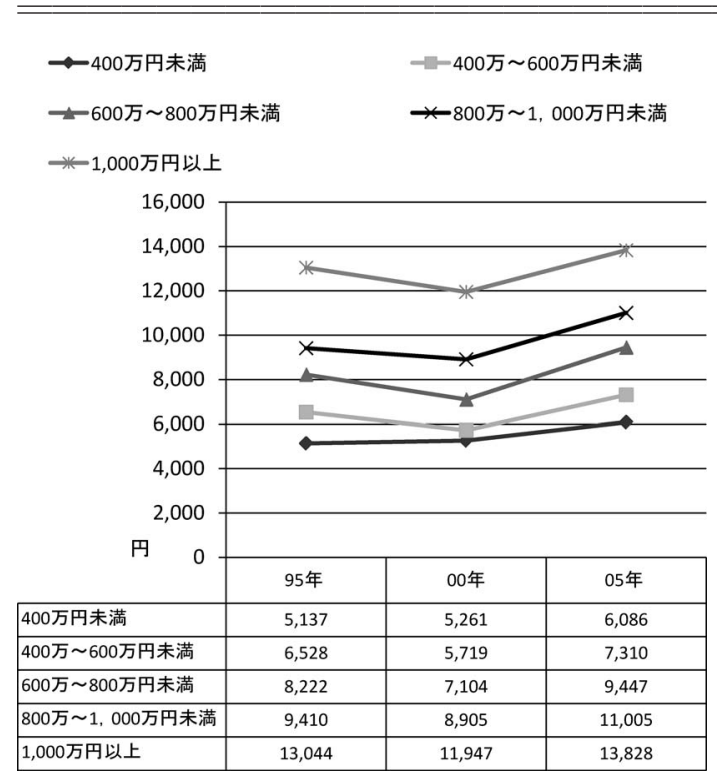

図 3-1) 幼児の生活アンケート 世帯年収別 1 カ月 の平均教育費

* 年収 200 万円未満はサンプル数が少ないた め, 年収 400 万円未満の中に含めて集計

* 無回答は除く

少ないが，参考值としてあげた)。全体的にみる と, 95 年時点では, 母親の学歴が高くなるほど平 均教育費が高くなる傾向があったが，05 年にな ると, 四大卒と短大卒の差が縮まり, 高卒との差 が開く結果となっている。短大を含む高等教育を 受けた母親と高校卒までの母親の間で, 子どもの 教育にかける費用の差が開いてきたことがわか る。

\section{2. 習い事の実施率の変化一「英語」と「スイミン グ」}

未就学児の教育費の中でも費用のかかる習い事 の実施率には変化が見られたのだろうか。図 5 は 家庭外で行う，お屯な習い事や塾その他の活動の 実施率をまとめたものである。95 年から 05 年の 10 年間の推移を見ると,「スイミングスクール」 (以下「スイミング」と表記) と「英会話などの語 学の教室」(以下「英語」と表記) に大きな变化が 見られた。「スイミング」は実施率の高い習い事の 代表的なむのだが， 95 年の $21.7 \%$ が最む高く,

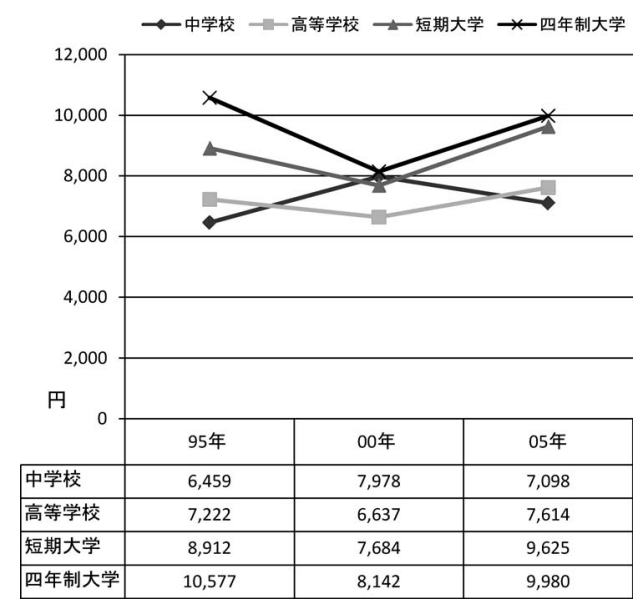

図 3-2) 幼児の生活アンケート 母親の学歴別 1 力 月の平均教育費

その後, 00 年に $16.0 \%, 05$ 年に $17.5 \%$ と減少し てきている。また，「英語」は 95 年に $5.8 \%$ ったた のが, 00 年には微減し $5.0 \%$ になるのの, 05 年 には $14.2 \%$ と大幅に増加した（図 4)。

「楽器 (個人レッスン)」や「音楽教室」「絵画 教室」,「習字」など屯減少し, 芸術系の習い事に は陰りが見られた。大学進学者が学部選択をする ときに, 教養系学部より法律・経済や，医療系な ぞ資格を取得できる学部を選ぶ傾向があるが，子 どもたちの習い事においてす，情操を豊かにする あのよりあ実学的なものが選択される傾向がみら れる。

では, 大きな変化のみられた「スイミング」と 「英語」について, 世帯年収や母親の学歴によって 実施率に違いが見られるのだろうか。

「英語」については，95 年の段階では年収層別 による実施率の差は小さく，8.6\%から 3.5\%の間 に収まっている。それに対し，05 年になると，と くに年収 800 1000 万円未満と 1000 万円以上 


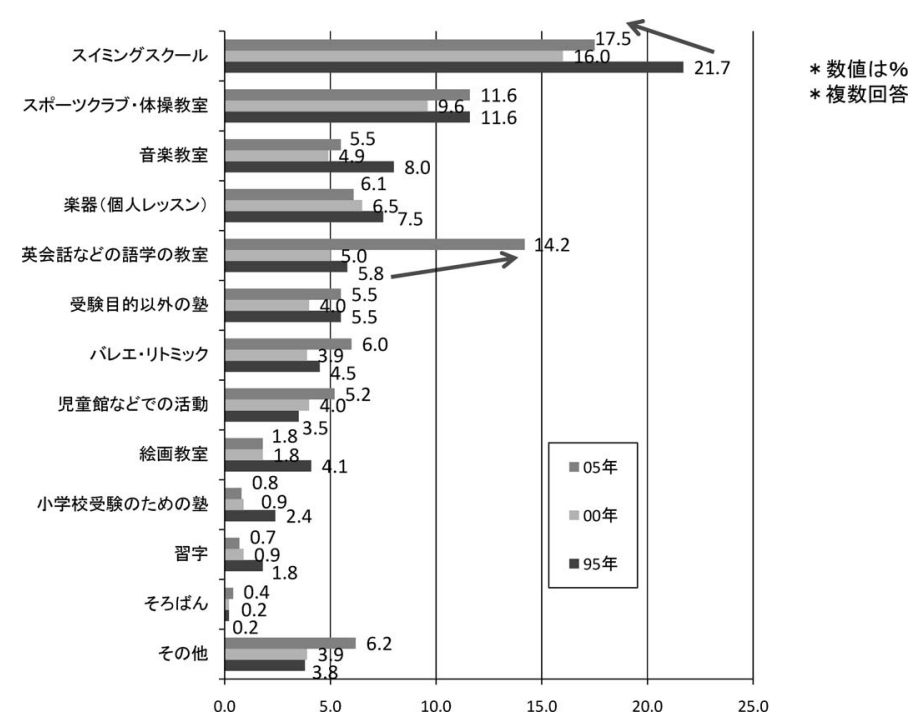

図 4 幼児の生活アンケート 習い事の実施率の推移

\section{英語}
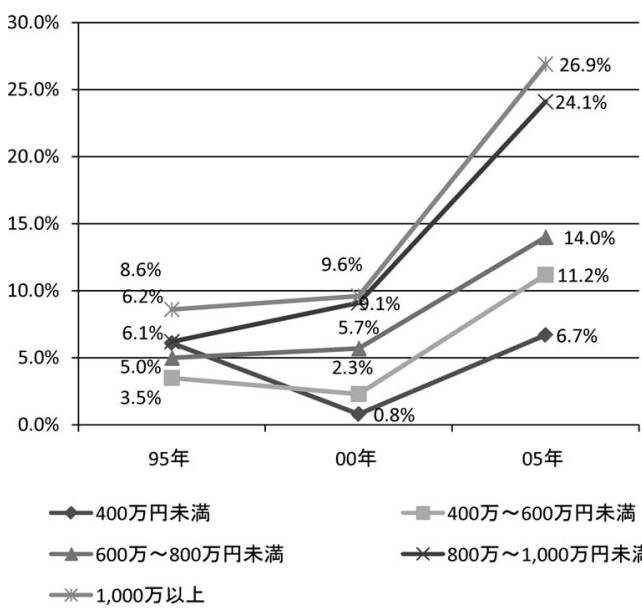

図 5-1 幼児の生活アンケート 世帯年収別「英語」 の実施率

* 年収 200 万円未満はサンプル数が少ないた め, 年収 400 万円未満の中に含めて集計

の高年収層はどちらも 95 年と比較して約 18\% 上昇している。同様に年収 600 800 万円未満で 9.0\%，400～600 万円未満でも 6.2\%増加してい るが，400万円未満ではわずか $0.6 \%$ しか増加し ていない。00 年以降，世帯年収の高い層は「英 語」を選択する率が一気に増加したことがわかる

\section{英語}

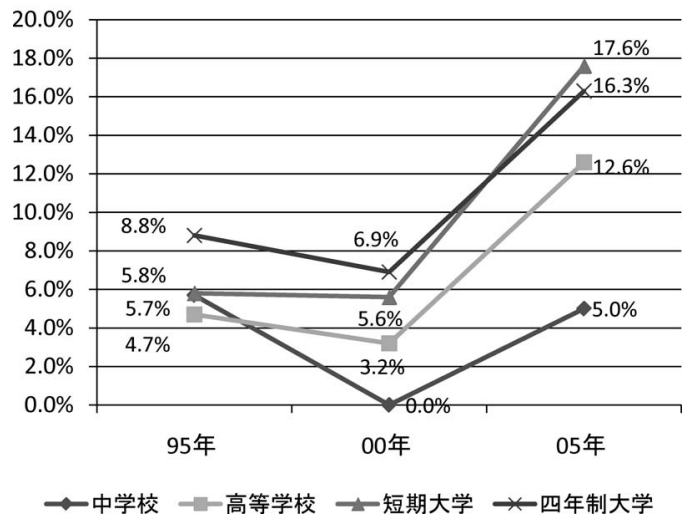

図 5-(2) 幼児の生活アンケート 母親の学歴別「英 語」の実施率
(図 5-(1))。

母親の学歴別に「英語」の実施率の推移をみる と, 95 年の時点では四大卒が $8.8 \%$ だが，学歴に よる差は顕著には見られない。ところが，05 年に なると大きな差が出た。短大卒 $17.6 \%$, 四大卒 $16.3 \%$ となり，高等教育を受けた母親は高卒の母 


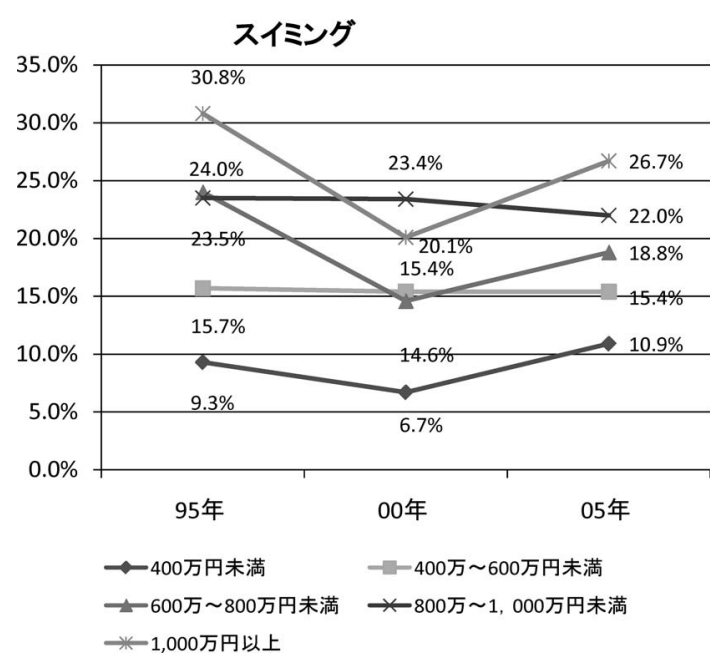

図 6-(1) 幼児の生活アンケート 世帯年収別「スイミ ング」の実施率

*年収 200 万円未満はサンプル数が少ないた め, 年収 400 万円未満の中に含めて集計

親の $12.6 \%$ 引き離した。また，わずかだが，四 大卒よりも短大卒のほうが実施率が高い結果と なった（図 5-(2)）。

95 年から 05 年の 10 年間で, 習い事としての 「英語」の実施率が大きく伸びたが, 年収や母学歴 の高い層が「英語」を選んでいる。企業間の M\& A などが進み, 日本企業の中には外資系に買収さ れる企業も出てきた。経営幹部のみならず, 中堅 層の中にも英語力を必要とされる層が出てきてい る。そのようなグローバル化への変化を敏感に感 じ取った層が英語を選択するようになっているの かあしれない。あるいは，このような保護者の ニーズに呼応して習い事としての「英語」の受け 皿が多く用意されたため, 実施率が伸びたのかむ しれない。幼児向け英語教材や教室ビジネスも進 展を見せているからである。なお，08 年にべネッ セで幼児の母親を対象に実施した調査では, 就学 前の習い事として「英語」を選択する率がやや 減ってきており，一時の熱が沈静化している傾向 が見られた。

「スイミング」は体育系習い事で最む人気があ る。その理由として，体が丈夫になる，小さいと

\section{スイミング}

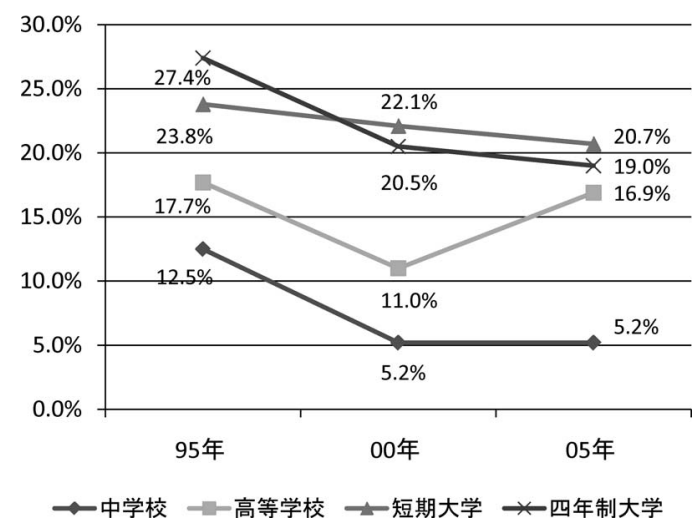

図 6-(2) 幼児の生活アンケート 母親の学歴別「スイ ミングの実施率

きから習得していれば小学校の体育の授業で困ら ない，目標が明確で継続しやすい（泳げる距離を 伸ばす，複数の泳法をマスターするなど）などが あげられる。70 年代半ばから, 子どあたちの習い 事の中では上位を占めてきたが，ここにきてやや 低下傾向が見られる。

年収層別に 95 年と 05 年を比較してみると, 低下または横ばいの層があるが，05 年の実施率 をみると，年収が高い層ほど実施率が高くなって いる。しかし，全体的に 95 年と比較すると実施 率が低下してきていることがわかる(図 6-1)。 また, 母親の学歴別にみると, 四大卒, 短大卒で 実施率が低下する傾向が見られた。とくに 95 年 と 05 年を比較すると四大卒は 8.4\%も減少して いる(図 6-(2)。この減少分が「英語」に移行して いる可能性ああるが，他のスポーツ系習い事を選 択している可能性むある。95 年の時点では, 幼児 期のスポーツ系習い事の選択肢がそれほど多くな かったことああり，「スイミング」の人気が高い が，ベネッセで実施した別の調査によると最近で は，サッカーなどの地域スポーックラブへの参加 が増えており，相対的に「スイミング」を選択す 


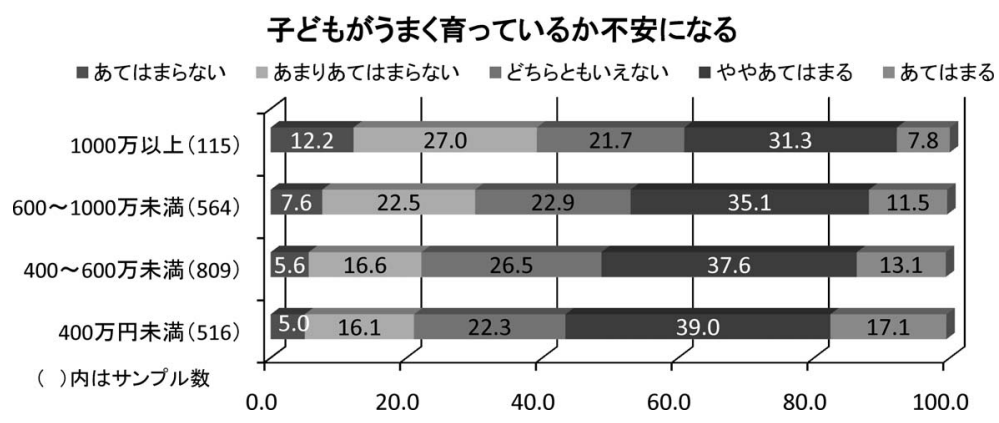

図 7-1) 妊娠出産子育て基本調査

子育てのためにいつも時間に追われて苦しい

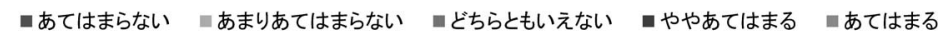

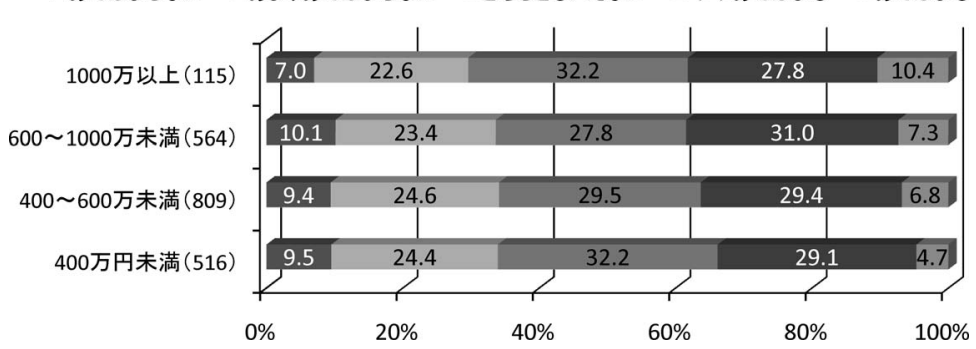

図 7-(2) 妊娠出産子育て基本調査

る率がやや減る傾向が出ている。「スイミング」の 実施率の低下にはそのような背景もあるかもしれ ない。

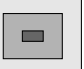

III. 世帯年収別に見た母親の子育 て意識

ここからは視点を変え，世帯年収別に見たとき の母親の子育て意識の違いについて, 2006 年に 実施した『妊娠出産子育て基本調査』(2) のデー夕 をもとに論じたい。子育て意識を聞いた質問への 回答を世帯年収 400 万円未満のやや低い層と 400～600 万円未満の中位層，600～1000 万円の 上位層， 1000 万円以上の超上位層に分けて傾向 の違いがあるかどうかをみてみた。年収層による 違いが出てきた項目は「子どもがうまく育ってい るか不安になる」「子育てのためにいつも時間に 追われていて苦しい」の 2 項目だった。

「子どあがうまく育っているか不安になる」で は，世帯年収 400 万円未満の層に「あてはまる」

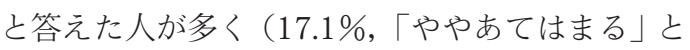
合わせると $56.1 \%) ， 600 \sim 1000$ 万円以上の 11.5\% (「ややあてはまる」と合わせると 46.7\%), よりあ 5.6 ポイント高くなっている。子育てへの 不安の要因はさまざまなあのが考えられるが，経 済的ゆとりもその中の一つとして，影響を及ぼし ていると思われる（図 7-1)。

これとは逆に「子育てのためにいつも時間に追 われて苦しい」は世帯年収 1000 万円以上で 10.4\%なのに対し，400万円未満で $4.7 \%$ 万たた (図 7-(2)）。年収が高いほうが生活に余裕があるよ うに見えるが，母親の勤務状況をみると，世帯年 収 1000 万円以上では, 常勤職が $36.5 \%$ を占め, 無職（専業主婦）は $34.8 \%$ ったた。れに対し， 年収 400 万円未満の場合, 常勤職は $3.3 \%$ と低 く, 70.0\%は無職 (専業主婦) が占めている。

世帯年収が高い層の中には共働きの結果, 年収 が多くなっている夫婦が含まれ，「時間的余裕が なく，子育てのためにいつも時間に追われて苦し 
い」という状態の母親が存在することがわかる。 常勤職の場合, 労働環境が変化する中で正社員の 仕事は長時間化する傾向が見られる。成果主義を 導入する企業もあり，一人ひとりの責任は重く なっている。仕事と生活の両立支援策が導入され てきてはいるものの, 職場では時間あたりの生産 性を上げることが求められているのかもしれな い。

また，最近では母親自身がよい母親であろうと する傾向が強まってきている。この 10 年あまり, 家庭教育を健全にするため, 生活習慣や食育など をテーマとする発信が行政やメディアによって行 われている。それに応えようと努力している母親 たちの意識の变化が見られる。しかし，そのため には家庭の中で子育てに充てる十分な時間や精神 的ゆとりが必要になってくる。世帯年収が高い層 には問題がないように見えるが，仕事と子育ての 両立に課題を持つ共働きの母親が含まれているこ とを見落としてはならないだろう。

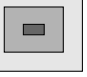

\section{IV. 結}

1995 年から 2005 年の 10 年間の世帯年収は 全体的に減少傾向が見られた。しかし，それにも かかわらず，1 カ月あたりの平均教育費は増加傾 向が見られた。年収が減少しているのに教育費は 増加しているので，この 10 年間で世帯年収に占 める教育費の比率は上がっていることになる。学 力低下を危惧する世論が就学前の子どあを持つ保 護者にも影響を与え, 習い事などに使う金額が増 えていることがわかった。母親の学歴別に子どあ 一人あたりの平均教育費をみると, 高等教育（短 大も含む，以下同）を受けた母親と高卒の母親の 間で, 95 年から 05 年の 10 年間で, 教育にかけ る金額の差が大きくなっていることがわかった。 また，習い事などの実施状況をみると，高等教育 を受けた母親で英語の実施率が高くなっているこ とがわかった。将来のために幼児期から行う習い 事として, 高収入・高学歴層で英語の実施率が高 くなってきている。
世帯年収別に母親の子育て意識をみると，低い 層は「子供がうまく育っているか不安になる」を 多く含み，高い層は「子育てのためにいつ屯時間 に追われて苦しい」が他の層と比較して多かっ た。年収が高い層の中には共働きの夫婦が多く含 まれ，子育てに悩みを抱える母親のいることが推 測できる。

このデータをまとめ, 日本家族社会学会で発表 したのは，2008年 9 月 7 日だった。米・大手証 券リーマン・ブラザーズの経営破綻の直前であ り，その後の社会情勢を見ていると，さまざまな ことを考えさせられる。今後, 乳幼児期の子ども たちむ保護者の経済状況の影響を少なからず受け ていくだろう。中学受験のように, 高額の教育支 出の機会が少ないので，格差は見えにくい。しか し，習い事のみならず，家族で経験する余暇活動 や日々の生活の中でどのような環境が作られてい るか，ということにも視野を広げるとさまざまな 機会の差が将来の学力や社会的地位の差に結びつ いていくかもしれない。ベネッセで実施している 基本調査は経年で実施しているので，今後もこの 問題に関心を持ち続けていきたい。

なお, 最後に, 学会発表を通して重要な社会的 テーマに微力ながら取り組む機会を与えていただ いたことに感謝申し上げたい。

\section{【注】}

（1）『乳幼児の父親についての調査』2006 年 3 月発 行 ベネッセ次世代育成研究所

$* 2005$ 年 8 月に首都圈在住の 0 歳〜就学前の 幼児を持つ父親にインターネットで調査。有 効回答数 2,958 人。

（2）『妊娠出産子育て基本調査』2007 年 10 月発行 ベネッセ次世代育成研究所

* 2006 年 11 月に全国の妊娠後期から 2 歳の 乳幼児をむつ夫婦に郵送法でアンケートを実 施。有効回答数 4,479 人, 回答率 $36.1 \%$ 。

（3）『幼児の生活アンケート』第 1 回報告書 1996 年, 第 2 回報告書 2001 年, 第 3 回報告書 2006 年発行 ベネッセ教育研究開発センター $*$ 第 1 回調查 1995 年 2 月, 首都圈の 1 歳 6 
か月〜6 歳就学前の子を持つ母親に郵送法で アンケートを実施。有効回答数 1,692 人, 回 答率 $56.0 \%$ 。

第 2 回調查 2000 年 2 月実施。首都圈求よ び抽出された地方都市の 1 歳 6 か月〜 6 歳就 学前の子を持つ母親に郵送法でアンケートを 実施。有効回答数 3,270 人。回答率 $58.4 \%$ 。 経年比較デー夕は首都圈の回答者のデー夕の
みを使用。

第 3 回調查 2005 年 3 月実施。首都圏の 0 歳 6 か月～6 歳就学前の子を持つ母親に郵送 法でアンケートを実施。有効回答数 2,980 人, 回答率 $41.4 \%$ 。経年比較デー夕は 1 歳 6 か月〜6 歳就学前の母親のデータのみを使 用。 